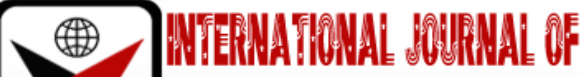

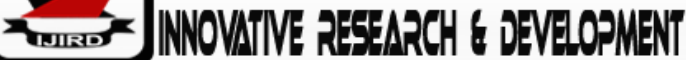

ISSN 2278-0211 (Online)

\section{The Politics of Unification of the British-Northern Cameroons with Nigeria: 1945-1961}

\author{
Dr. Adamu Sani Buba \\ Assistant Lecturer, Department of history, university of Maiduguri, Borno State, Nigeria \\ Zulkanain Abdul Rahman \\ Professor, Department of History, University of Malaya, Kuala Lumpur, Malaysia
}

\begin{abstract}
:
This article examines the politics that surrounded the unification of this territory with Nigeria during the first and second plebiscites sponsored by the United Nations, under the United Kingdom for the part of the Northern section of former British-Cameroons amalgamation with Nigeria, in 1961. This region, with its diversity in both ethnic and geographical pattern. Therefore, considered as a large whole because of the nature of its common historical root. The territory was quite remarkable with a unique historical occurrence. It was once a catalogue of slaves for the rulers of the trust territory, perhaps, with the exclusion of the Kanuri Empire of Dikwa emirate? Similarly, it was a German Protectorate; later transformed into a League of Nations mandate; furthermore, hitherto metamorphosed, turn out to be a United Nations trust territory, before finally unified with Northern Nigeria and part of the Federation of Nigeria in 1961. We may infer that no part of Nigeria that has experienced such a significant historical feel. More especially, the contributions of the Prime minister traditional rulers and the Premier of Northern Nigeria on the unification process. The aim is to trace the process and contribution of educated Northern Nigeria elites, which led to the union. The question that comes to mind is why did the first plebiscites fail? The objectives of the union were to uphold the legacy of the Sokoto Caliphate, and ensure that the Northern strips adjoining Adamawa, Borno and Benue (formerly known as the British-Northern Cameroons) unified with Nigeria. This article finds out that educated northern elites and traditional rulers, especially the Prime minister and the Premier of Northern Nigeria have played a vital role in the union process.
\end{abstract}

Keywords: Politics, educated elites, traditional rulers, unification, northern Cameroons, Nigeria, united nations

\section{Introduction}

Yola, the Capital of Adamawa state was the headquarter of the Northern Cameroons, and Mubi headquartered the districts on the North, while Jada was Temporary headquarter of the Southern districts. As the Northern Cameroons voted resoundingly for the reunion in the second plebiscite in 1961, and the separate strips from Adamawa to Dikwa were prompt, made a thirteenth regional province, which took effect from June $1^{\text {st }}$ for the official reunion date, and beards the novel name Sardauna Province. Moreover, became the second smallest province after Kaba, with about 750,000 population, which lost its identity as Northern Cameroons in 1961. Perhaps, named after the Sardauna (Sardauna is a title given to a trustworthy individual) of Sokoto Sir Ahmadu Bello the grandson of the propagator of the Sokoto Jihad, 'Uthman bi Foduye, (bi means bin. in Arabic) who made sure that the legacy of the Sokoto Jihad was maintained.

However, this territory was formally a German protectorate later transformed into a League of Nations' Mandate later became a United Nations Trust territory. It was under the United Nations that the trust territory finally unified with the Federal Republic of Nigeria in 1961.This territory as earlier indicated comprised of Cameroon's under British mandate and trusteeship. This region is predominantly mountainous, lay on the eastern part of the Nigerians. Stretching inland for some 700 miles from the Atlantic Ocean to the Lake Chad with an average of about 50 width miles, terminated in the North, by a gap of about 45 miles which contained from the valley of the River Benue and in which the territory of Nigeria and Cameroons formerly under French trusteeship met. 


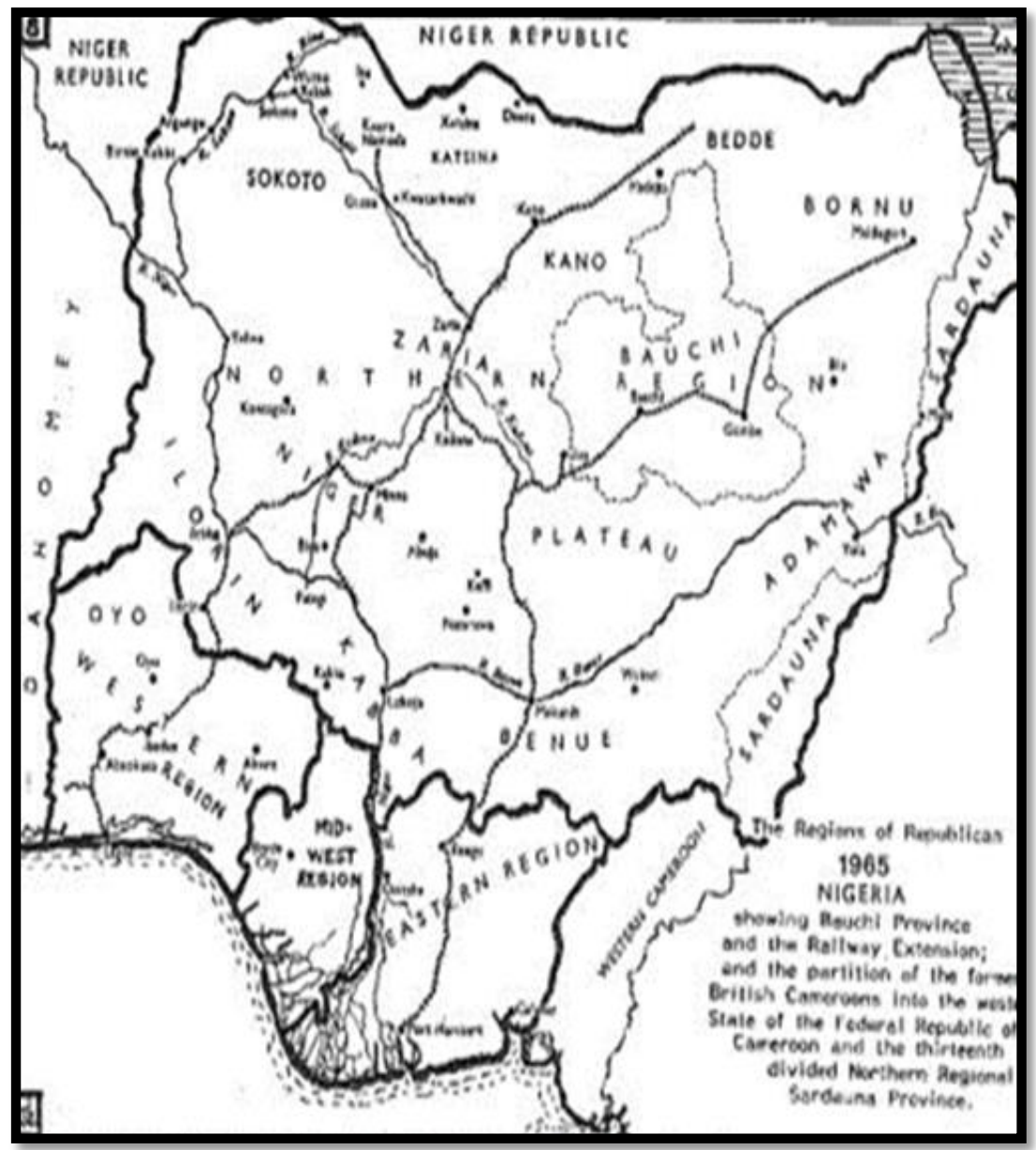

Figure 1: The Map of Regional Republic of Nigeria after the Plebiscite 1961 Sources: Clark, T., the Right Honourable Gentleman: Hudahuda Publishing Company, Zaria, 1991

\section{The British Administration under Trusteeship Council (1946-1961)}

On 13th December 1946, the British administration of the trust territory under the mandate replaced by the trusteeship. The approval of the continuation of the administration under the trusteeship by General Assembly of United Nations due to the various reports submitted to it during the administration under the mandate and said to be for the best interest of the inhabitants of the territory. It was on the basis of this that the trusteeship agreement was approved by the General Assembly. Article 10 of the mandate requirement, reports were submitted annually to the League of Nations, through its permanent mandate commission, for instance, 1921 the first report informed the permanent mandate commission on how the territory was administered by His Britannic Majesty through the Government in Nigeria:

In the circumstance, it has been found convenient similarly to divide the territory in the Cameroons which is now under the administration of Nigerian government into Northern and southern half of which has been added for administration purposes to the group of provinces to which it geographically belongs and has been placed under the charge of Lieutenant-Governor who is responsible for that group. Whereas, however, the area comprising the Northern portion of the Cameroons territory under British administration has been again subdivided into two portions of which the more northerly is administered by the Resident of the Nigerian province of Borno and the more southerly by the Resident of the Nigeria province of Yola it has been found most convenient to treat the part of the Cameroons which is attached to the Southern province a separate provincial entity and to post to the charge of it a Senior Resident assisted by a small staff of political officers. ${ }^{1}$

However, the League of Nations after carefully studied the mandated report in its fifth session, comments as follows:

'In view of the geographical configuration of these the territories and the ethnic composition of this populations, the commission is fully prepared to admit that the measure adopted by the mandatory power may be the best calculated to ensure good administration and consequently the well-being of the population. It desires to add that these measures are more expressly authorized by the terms of the mandate provided that they do not lead to any infringement of the general provision thereof'. By their mandatory power had the right to administer the territories concerned 'as integral portions of its territory'.2

The commission adds that:

This does not mean that the countries concerned have become integral portions of the neighbouring colonies as the wording of certain passages in the reports on Togo land and Cameroons would appear to suggest. While the commission desires to bring this matter to the notice of the council it does not exaggerate its importance. As however, the passages referred to might lead to annexationist aims being attributed quite 
erroneously to the mandatory powers it appears to the commission that their own interest no less than that of the league of nations requires that in future any formula should be avoided which might give rise to doubts on the subject in the minds of ill-informed or ill-intentioned persons. ${ }^{3}$

The mandatory powers in their reports to the mandate commission made their position abundantly clear and therefore, worth quoting in full:

It may be stated with confidence that no such tendency (a tendency of the local administration to consider the mandated territory as an integral part of Nigeria and to lose sight of the vital differences between Nigeria under the sovereignty of Great Britain and the Cameroons a territory under mandate), exists and that both the mandatory power and the local administration are fully aware of the vital difference which exists in the status of the two towards annexation of the Cameroons under British mandate by Nigeria should be advanced when every effort is made to observe the condition of the mandate and to administer the territory so as to serve to the best advantage the well-being and development of the people. It must be realized that the governing factor in the administration of the Cameroons under British mandate is geography. The territory is a long narrow strip of country which is broken in the middle and it contains a diversity of peoples. It is in fact not a country, in the ordinary sense of the term, but a geographical expression, it reads: For this reason, the territory is administered as an integral part of Nigeria although it is not, and will not become, an integral part of that century. Its size, situation and bipartite sharp at present preclude it from being financially autonomous if the standard of the administration and development is to be maintained, at a level which would be compatible with the due performance of the obligation of trusteeship. The economic advantages which accrue to such a territory as the Cameroons the under British mandate from being administered as an integral part its greater neighbour - Nigeria are indeed many and, by utilizing the resources of central and departmental organizations of Nigeria, the mandatory power is able to offer advantages to the mandated area which it would be impossible to offer to an area under an entirely separate organization. ${ }^{4}$

It is in line with the above explanation, of the government of the United Kingdom to the satisfaction of the United Nations, that the British could administer the territory in the manner, described above. Perhaps, it is within the same framework that the territory was administered through the indirect rule system, which was also the principle that governed Northern Nigeria. The system of indirect rule instils the use of traditional institutions in governing the inhabitants of the territory. According to the British, the system was to educate the local inhabitants 'to manage their own affairs and to evolve from their own institutions a mode of government which shall conform to civilized standards' in doing so, the mandatory power considers:

It needs scarcely be said that the policy of indirect rule administration can and must be applied in a variety of forms and degrees. The highly organized state of Dikwa cannot be dealt with on the same lines as the primitive hill Pagans who are still in a state of Savagery. But between these two extremes a number of communities whose administration calls for a variety of treatment. ${ }^{5}$

\section{Constitutional Development}

As the administration of the trust territory of Northern and southern Cameroon continued under the trusteeship council, and, as the political development continued to take a centre stage linked closely to that of Nigeria. Thus in 1947, a new constitution came on board to replace that of 1922. The most important feature of the constitution was the induction of a policy of regionalization, by this policy, it meant that subsequently, Northern Cameroons be part of the Nigerian constitution. The significance of this constitution was the establishment of Regional Houses of Assembly in the Eastern, Western and Northern Nigeria, respectively. In addition to this was a special House of Chiefs for the Northern region the reason for this Houses of Assembly was having to link between the central legislative council and the Native Authority who oversaw local government administration. In which more than half of the unofficial members of the central legislative council were eligible for election by the unofficial numbers of the Regional Assembly. Under the new constitution, the Northern part of Cameroon trust territory had representatives in the Northern Regional House of Assembly and in addition to the Emir of Dikwa under (Borno) who as a first-class chief was, 'ipso facto' a member of the Northern Regional House Chiefs. While the southern Cameroons had a representative in the Eastern Regional House of Assembly. ${ }^{6}$

In 1949, a commission was appointed and given a special responsibility to administer the South Cameroons and responsible for the whole of the trust territory. In the same year, 1949, extensive constitutional amendments began, this time to revise the 1947 constitution, for the first time the trust territory participated fully in the process of the constitutional amendment and at all levels. ${ }^{7}$ By 1951, a new constitution was introduced, had at the centre, the council of ministers and a House of Representatives with one member from each of the three Regions on the House of Assembly, the North and western regions had Houses of Chiefs. Elective Positions went to the majority of the House of Assembly, which is members of the House of Assembly were elected, while the former by Houses of Assembly, the latter, through the electoral colleges. Each of the regions had equal representation on the council, but a nomination to the council of the ministers was subject to the approval of the joint council of the Northern and Western Regional Houses of Assembly and by extension the Eastern Region House of Assembly. Under this arrangement, all adult male taxpayers could elect members of the House of Assembly.

However, under the constitution of 1951,Southern Cameroon had 12 members on the new Eastern House of Assembly, with one member as minister to be elected or appointed from the inhabitant of the southern Cameroon, for the council of ministers, of the Federation of Nigeria, twenty-one seats out of the total, number of ninety-one (91) in the Northern House of Assembly went to the provinces, of the Northern Cameroons when the first election under the 1951 
constitution, was held, Southern Cameroons, had six members in addition to the one minister in the central Council of Ministers, in the House of Representative, and two from Northern Cameroons. There were two Southern Cameroons members in the Eastern Regional Executive Council and thirteen southern Cameroons members in the Eastern House of Assembly, Northern Cameroons had three members in the Northern House of Assembly and one in the Northern House of Chiefs. ${ }^{8}$

However, in 1953 and 1954, yet another consultation and discussion held for yet another constitutional amendment on 1st October 1955, the newly amended constitution came into force. By this constitution, the Northern part of the territory continued to administer along with the Northern Region of Nigeria. As for the southern part of the territory, it acquired a status of a separate region with a federal constitution. In addition, it had its own executive council and some elected African members on an equal basis, it also had its own House of Assembly with an overwhelming majority of elected African representatives. In this case, a new portfolio, for trust territory affairs, created in the Northern region executive council held by a representative of the Northern part of the trust territory. Now, in 1955, a consultative committee for the Northern Cameroons, and to make a recommendation to the council. ${ }^{9}$

The committee had the twelve (12) member which was drawn from the House of Chiefs, House of Representatives and the House of Assembly, who is the representative of the Northern part of the trust territory, and special members who were not represented in any of the above council. The reason for the formation or setting of this committee was to advise on how best the trust territory was administered. However, in 1955, the committee after deliberation unanimously agreed that under no circumstance, the trust territory was amalgamated with the Southern Cameroons. ${ }^{10}$ By this recommendation of the committee merited that the Northern trust territory remains part Northern region of Nigeria.

In 1957, this time a conference held for yet another Nigeria constitutional revision, thereafter it agreed that changes should be made, and in 1958, the southern Cameroons got its own constitution like that of Nigeria. It was from this point that the southern and Northern Cameroons under the trusteeship council divided and administered separately based on the constitution of each region. Now, the Southern Cameroons having got this own constitution, the ministerial system of government introduced, with an established executive council. Because of these changes in constitutions, the Northern Cameroon consultative committee was enlarged, thereby increased the number of representatives which included the 'remoter districts', and a formal committee of the executive council of the Northern region to keep the affairs of the territory at all times before the regional government. ${ }^{11}$

So, the South Cameroon House of Assembly in 1958 demanded that full regional self-government in 1959. This matter deliberated upon in London at a constitutional conference and replied that until such time the people of the territory were elected. Accordingly, until the region was fully and equal in status to the region of Nigeria, they further maintained that effect given to this decision in November 1959 after the wishes of the people had ascertained in the election of January 1959. The election was based on universal adult suffrage. It was further agreed that the Northern region of Nigeria, with which the Northern Cameroon countries to be administered would become 'self-government' region within the Federation of Nigeria March 1959.12 The trust territory under the United Nations supervision the administration of the trust territory was in accordance with Article sixteen of a trusteeship agreement.

In this the United Kingdom as was the Administering Authority, and as part of its responsibility, it presented an annual report to the trusteeship council on the Trust territory. The United Kingdom through its Agent, the British, presented a report from 1947 to 1959, as provided also by Article 88 of the charter of the United Nations.

In addition to this, the Trusteeship appointed visiting mission who visited the territory at different occasions, especially, the periods of 1949, 1952, 1955 and 1958, carried a thorough check and investigation concerning the administration of the territory, especially the views of the inhabitants with a view to drawing the attention of the trusteeship council. ${ }^{13}$ These reports were at a different point in time considered by the trusteeship council. There was also a constituted administrative committee on unions, which was established under resolution 81 on 27 th January 1949 , responsible for and on behalf of the trusteeship to keep an eye on the operation of the joint Nigeria Cameroons administration and periodically reported the aid of progress or otherwise on the territory. We may infer that this responsibility was a complete survey on the operating system of the trade unions in all the trust territories under the British administration.

Furthermore, after due consideration of the reports of the committee, the trusteeship found them satisfactory especially in political advancement within the framework of the constitutional development, which proceeded steadily. The trusteeship noted that the needs of the people had met, and therefore, consideration of the reports. The General Assembly of the United Nations adopted the reports of the trusteeship council. The trusteeship council in its first meeting in 1949, on the political advancement of the territory, observes that:

The council concerned over the deficiently in performing its supervisory function with respect to the trust territory, arising from the fact that the territory has been integrated for administrative purposes into different administrative division and sub-divisions of the British protectorate of Nigeria.... recommends that pending a final solution of the question of these administrative arrangements, and administrative authority review the situation and take steps or institute measures... which will enable the trusteeship council better to perform the duties and functions vested in it by the charter. ${ }^{14}$

Moreover, on the part of the visiting mission to the trust territory on behalf of the trusteeship council in 1949, Notes that: On the general question of the administrative integration of the Cameroons with Nigeria, the mission appreciates the force of the arguments on both sides. Without attempting to comment on or evaluate the principle of this administrative association, which it feels ought to be left to the trusteeship council, it found that the sharp difference between the north and south with its contrasting culture, religion, race language 
and general way of life does not fortify the argument of a total separation from the administrative point of view, from the district with which they are now integrated. ${ }^{15}$

The mission did not view its duty as including the evolution of merely theoretical consideration but consider that expected to report 'objectively based on facts'. 'Everything the mission had seen went to confirm the fact that', with the contrast between the north, apart from the very numerous pagan populations, and the south of the trust territory, the north is neared and more allied to the Northern Province of Nigeria in its religion, race, culture and language. In the case of Adamawa, it is possible to draw a line or to differentiate between the two since the same people live in the same region, headed by the same ruler. Therefore, the North of the trust territory is smoothly administered in conjunction with the northern province of Nigeria than perhaps with the southern of the trust territory.

Similarly, the Northern part of the trust territory referred to is Borno region which had a more elaborate administrative system which was easily administered through the indirect rule, as compared to the southern part of the trust territory of Adamawa, which was more complicated, as it did not have a central administrative system. So, having considered the above, the trusteeship council in its sixth and seventh season in July 1950, decided that; 'The question of the administrative integration with Nigeria shall be considered, and any necessary recommendation formulated, in connection with the discussion on the general question an administrative unit in accordance with the General Assembly resolution'. 16

The resolution of the trusteeship council further requested the committee on administrative union should thus: 'Continue to study the question arising in connection with the customs, fiscal, and administrative unions of the federation and common service involving trust territory'17. The above explanation now gave the committee on the administrative unit to continue a regular examination and progress within the trust territory in relation to the administrative unions.

However, on 4th August 1959 to the fourteenth session of the General Assembly, the trusteeship council explains that:

The present constitution of the Federation of Nigeria which by virtue of Article 5 of the trusteeship agreement is also the constitution of the trust territory....18

The implication of this is that the constitution of the Federation of Nigeria affected both the British - Northern Cameroons and Nigeria. Actually, the trust territory administered in accordance with the trusteeship council agreement as an integral part of Nigeria. This matter was further presented at the fifteenth season of the General Assembly on 30th June $1960 .{ }^{19}$

\section{Unification Process with Nigeria}

As earlier discussed, this territory was at first a point in time a German protectorate; it transformed into the league of Nation's mandate and later became a United Nations Trust Territory. The territory continued to develop in various ways under the guidance of the United Nations and finally unified into the Federation of Nigeria in 1961.

Undoubtedly, the efforts to unify the portion of this trust territory with Nigeria started from the period of 1914; this period was a period of the First World War, when Lieutenant Colonel Conifer, commander in charge of the Nigerian Regiment, invaded Northern Cameroons from the Northern Protectorate. This lasted for about one year, subsequently, the Germans were ousted out of the territory and fall under the control of colonel Conifer who was answerable to the Governor-General of Federation of Nigeria. It may be assumed that it was from this point that the colonial government of the Federation of Nigeria took it upon its self to administer this territory on behalf of the League of Nations.

As the political policies of the British on the conquered territory began to unfold, it became certain that the British colonial government intentions were too regained back all territories which had hitherto been lost to GermansCameroons during the period of partition and boundary delineation between the two colonial powers in the period of (1882 to 1894$).^{20}$

Similarly, one significant thing that sealed the fate of the region was certainly, the Anglo/German Agreement of 1893, obsessed by its desire to block French from gaining any access to the Niger-Benue Regions, the British rushed into granting the German virtually the entire region. Now this time the struggle is between the British and French over the Cameroons, in fact, the British colonial government in Nigeria made efforts in championing the cause of African rulers and the pre-colonization between Nigeria and the Northern Cameroons. By this, the colonial government wanted to make sure that all lost territorial of Adamawa and Borno Provinces, regained and secured. The practical area, which the Nigeria government wanted to secure was about half the Cameroon Republic. ${ }^{21}$

Sir, Frederick Lord Lugard, who considered regarded as an empire builder, wanted the colonial office to state out claims for the whole of the territories formerly under Adamawa and Borno. Perhaps, to make the British government strove more to see the territory annexed to Nigeria, Ruxton, the British resident in Maiduguri Borno State, wrote to the colonial office in London, that the number of semi-Arabs (Shuwa Arabs) in Dikwa was greater than that of the BritishBorno. This was a plus to Lugard, who during his period of administration, could not conceal his affinity for the Fulani and the Shuwa Arabs who were according Charles temple 'Caucasians' so, were more important to him and his administration than was the negroes. For Lugard, the restoration of the lost territory was the minimum demand he could allow. The claims of Lugard were reflected in the Fulani and Kanuri historical claims, which practically for the Adamawa and Borno regions respectively. Lugard was of the belief that it was only through this means that the indirect rule system would be strengthened and achieved.

Therefore, Lugard was determined to restore back territory to the Modibbo 'whose loyalty in trying circumstance deserves recognition'.22 Again, felt, or of the view that so long as they remained under the control of the French, would have not only a damaging consequence but absorb on the British administration which depended on prestige and power. However, even though not all what Lugard wanted was given to him, he notwithstanding managed to get under his control the Northern Cameroons. Not only that it is worthy of mention that British was not comprehensively successful because both France, British, and other contending colonial powers, were in a real 'senseless interested in the kind of typical African' 
matter which the British were championing. The British only used them as an agent in this situation to expand and strengthened its territorial ambitions.

Yet, as mentioned previously, the British was only mandated to administer the territory on behalf of the League of Nations, but overall, the British apparently considered it as its own property. In 1945, the United Nations Organization came on board, to replace the League of Nations with a doctrine of self-determination for all the peoples and nations, it was from this point that dramatic change for the status of the territory, and its future brought into the light.

However, as for the future of the territory, the United Nations Charter, Article 76, stipulated for the trust territory, 'progressive advancement towards self-government and or independence'.23This is one of the differences between the mandate and trusteeship countries system. The trust territory is administered by the British and guided by the colonial government towards self-government and or independence. Even with this development, the Northern Nigerian government did not lose focuses on its main objective to acquire its lost territory. In one of the sessions in the United Kingdom, a British representative declared that the best course for the British - Cameroons was for all the people of the trust territory to participate in training towards self-government, which was taking place in Nigeria. He comments:

It was improbable that the Trust Territory in view of the artificiality of its territorial boundaries and the in heterogeneity of its ethnical composition, will ultimately become separate political entity, but-- - the people of the territory are being fully consulted regarding their wishes and it is expected that the forthcoming reforms to be made in local governments and the constitution will give them both a greater measure of local autonomy and larger representation in the Nigerian legislative ${ }^{24}$

Certainly, the above stresses the administration of the territory as integration with Nigeria. While the constitutional reforms referred to be certain, 1947, the constitution of Nigeria, which gave the Northern Cameroons a representation in the central legislative council and in the Bio Cameral Northern Regional Government. In addition, the authority and responsibility for the territory's office remain in Lagos. There was no provision for a separate system under the trust territory, but rather all revenues from the trust territory usually went into the common fund and were shard according to needs. The territory was running by the civil servants drawn from Northern Nigeria civil service, the visiting mission under the United Nations concerning the administrative system and its motives considered in this manner:

There are first the two areas, physically divided by the Nigerian territory administered as part of Adawama division of the Adamawa province, which also belongs to the Northern provinces, and secondly the Dikwa Division which forms a division of Borno province which again belongs to the Northern provinces. It seems as though the territory its self belongs to the Nigerian region. ${ }^{25}$

In 1959, the British - Cameroons was the only remaining trust territory under the United Nations in the whole of West Africa. As the United Nations was eager to see that all territories under it had a sense of belonging, the General Assembly and the Trusteeship Council of the United Nations in April 1959, in a special session in Cameroon, agreed on the future of the Trust Territory, in which extensive discussion was held and at the end of the meeting it decided or agreed upon that Plebiscite be held on November 1959, for the people to decide through election by ballot to join Northern Nigeria, when it became independent in October 1960, or alternatively defer any decision until a later date. Nevertheless, the General Assembly of the United Nations in its resolution recommends thus:

The Administering Authority in Pursuance of Article 76b of the Charter of the United Nations take steps in collaboration with the United Nations Plebiscite commissioner to organize, under the supervision of the United Nations. Separate plebiscites in the Northern and southern parts of the Cameroons under the United Kingdom administration in order to ascertain the wishes of the inhabitants of the territory concerning their future. ${ }^{26}$

By this recommendation of the United Nation, it further, recommended that the plebiscites be held in about the middle of November 1959, with the following question asked:

Do you wish the Northern Cameroons to be part of the Northern region of Nigeria when the Federation of Nigeria becomes independent? Or, are you in favour of deciding the future of the Northern Cameroons at a later date?

However, the General Assembly also recommended that the plebiscite was based on electoral register which was used for the Nigerian House of Representative elections. By this order, it stipulated that any person whose name appeared in the voters register under Article 5 of Nigeria (Electoral Provision) of 1958, and in respect of any district and the person was eligible under such a regulation to vote for the purpose, retiring a member to the House of Representative of the Federation of Nigeria were eligible.

\section{The Role of Northern Educated Elites in the Unification}

As mentioned earlier, Britain was the administering body in the Cameroons (under United Kingdom trusteeship) had been ostentatiously impartial under Macleod Iain's 'enlightenment campaigns' in preparation for the plebiscite under the United Nations supervision. Similarly, the Sardauna who was the Premier of Northern Nigeria had made sure that 'complacency or subversion' he detected in the first plebiscite of 1959 was not repeated by the field administrative staff and the native authority in the Northern strips (Northern Cameroons) which adjoined Adamawa, Benue and Borno. Certainly, there was no comparable federal counter to the local campaigns in the southern district of Cameroons and the Bamenda Provinces. The Prime minster of Nigeria, Sir Abubakar Tafawa Balewa made a radio broadcast before the poll. It sounds a practical eloquence and warning of a leader. He made it abundantly clear that:

Instead of peace and prosperity, instead of more schools, and hospitals, and improved communications, which you may genuinely expect from the reunion, with Nigeria, you will risk losing everything...I emphasized this word 'reunion' because until last October we had been together for forty years...In every 
single year from 1922 until 1949, the central government subsidized the southern Cameroons... this small country, with a population of under a million, will have a full status of a region,... the full allowance of twelve senators will be accorded, just the same as the north, east and west...nothing could give us greater pleasure than to welcome them back home again... you would throw in your lot with a country whose government had made no firm promises to you and has given no undertaking, a country which unfortunately has torn in recent years by civil wars...I cannot see how you can avoid living a life of poverty and hardship, and under the constant shadow of violence which the government cannot control. ${ }^{27}$

The Nigerian leader continued to give details of how generous Nigerian of Government had been to the Cameroons while under Britain administration from (1922-1958), but unfortunately, his listeners could neither absorb statistical sagacity nor despite their suspicions of the Cameroon leader then Ahmadou Ahijo and forgot their distrust of Enugu in far eastern Nigeria. Perhaps, as Clark puts:

He may have seen a reflection British electorate's reaction to Churchill's doomsday warning in 1945, when on plebiscite day the southern Cameroons voted for reunion with Cameroon as West Cameroon state, with a subordinate government'28.

The northern section voted resoundingly to return, and this brought the separate strips from Adamawa to Dikwa were promptly made the thirteen northern regional Province, which took effect from June and beards the novel name of Sardauna Province. This gain was outweighed, by Nigeria's imminent loss of many able and likeable citizens to bilingual and bicultural republic whose president was in power for about twenty-two years, in the person of Ahmadou Ahijo.

Undoubtedly, the president had cultural and religious ties with the north, and his opponents related closely with the new half-reluctant adherent between Bamenda and Victoria. However, there seems to be a diplomatic marathon at the background, by the then minister of state BamaliNuhu, seek to dampen down opposition to the reunion of Sardauna province with Nigeria. From the thirteen very strong Arab blocs at the United Nations Organisation (UNO) who aroused out of strong resentment at the spectacle of a man called NwachukuJaja, who was said to be 'enjoying luncheon' with his Azrael counterpart Mrs Golder Meir'. Unfortunately, Bamali had telephone Lagos and directed that Nwachuku be recalled on the next available flight ${ }^{29}$.

Sir Abubakar Tafawa Balewa and his ministers had decided that the Cameroon issue be left to history. Yet the educated Northern Nigerian elites especially the Prime minister and his ministers did not forget while 'Israel and France lobbied hard through United Nations to oppose any part of Cameroon to join Nigeria', similarly Britain seemed to have done nothing to back its Commonwealth partner'30.

In 1948 Federal constitutional reforms gave the Northern Cameroons a representation in Nigerian central legislative council, notwithstanding did not increase the number of Northern legislative seats in the council, the Macpherson constitution which allowed the principles of fifty percent Northern representative in the central legislature did not consider the additional population of the Northern Cameroons within the Nigerian Region, because of this, the territory was not directly been represented in the parliament. Not until 1957 when the ministry for Northern Cameroons was created under the Northern region that amendment was made to the constitution which gave the Northern Cameroons seven seats in the parliament thus increased Northern representation. With this development, the Northern region got more than half of the seats in the parliament in accordance with 'the principles of making regional representation proportional to each region's population'. ${ }^{31}$

Yet, it was from this point that it became clear the motives or reason for Northern region demanded the unification of the territory with Nigeria. Not only that the unification of the territory into the Republic of Cameroon would have caused the loss of seven seats in the parliament for the Northern Cameroons. Yet another consideration that pushed the government of Northern Nigeria, or Northern People's Congress (NPC) was the fact that like Northern Cameroons, Southern Cameroon, was to decide on February 11, 1961 option, of whether to join the Republic of Cameroon or Federation of Nigeria, it was discovered that if Southern Cameroon voted to merge with Nigeria and Northern Cameroons join the Republic of Cameroon the balance of power would have changed towards southern Cameroon. Nevertheless, found out to be the reverse, that is southern Cameroon voted to join the Republic of Cameroon and the Northern region retained the seven-seat of former Cameroons. Thus, the outcome of the plebiscites gave the Northern government of the NPC more confidence in its pursuit of national interest at the Northern point of view, especially about revenue allocation. It maintains that the revenue allocation based on each region's population rather than in accordance with each region's contribution to the revenue. This motion was adopted, which became in favour of the Northern region in comparison with the mineral-rich southern region.

Secondly, an imperialistic reason or motives may be discerned on how Lord Lugard, the master of indirect rule bent to get back all lost territories by any means possible. This he did through championing the ties or rather historical ties with the Adamawa and Borno. The Modibbo and Shehu were particularly interested in having the 'body' of their Kingdom and not the 'head' given back to them like the Modibbo and the Shehu sir, Ahmadu Bello the Premier of Northern Nigeria, was keenest in making sure that Northern Cameroons was united with Nigeria. This moved him probably, by the desire to Champion the historical ties between the territory and Sokoto caliphate. The premier and Sardauna of Sokoto was an aristocratic Fulani to the core and a Muslima direct descendant of Shehu Uthman Dan Fodio, the founder of the Sokoto caliphate, his grandfather had been the Sultan of the Caliphate ${ }^{32}$. In fact, the premier once held the position of District Head, and his greatest ambition was apparently to become the Sultan of Sokoto? No doubt, Sir Ahmadu Bello clearly resented the loss of the territory and considered it a mark 'of honour, pride and greatest achievement to get back what belongs to him'.33

The premier once pointed out clearly in fact made abundantly clear when he addressed the members of the Northern Regional House of Assembly on the challenges of the outcome of the 1961 plebiscite result, by the former 
president of Cameroon AlhajiAhmaduAhijo in 1960. In which the premier reminded members of the historical ties between the people of Northern Cameroons and Sokoto caliphate. The premier maintains that:

Mr Speaker, Sir, I don't want Ahijo to forget my ambition of regaining a part of his republic which was once part of the Fulani empire. To that end am fully occupied now. ${ }^{34}$

Undoubtedly, the difference between the objective of the Sardauna and that of the Modibbo the ruler of Adamawa and Shehu of Borno were obvious. For Adamawa and Borno rulers had a narrow thought of getting the territory to be part of their emirates, while the Sardauna emphasized to get back the territory for Northern Nigeria and Nigeria as a whole. So, the difference in the objective is discernible to some extent lookup by the Sardauna of the Northern Regional Government course was detrimental to the narrow interest of the Shehu and Modibbo. The Sardauna, moved by political expediency, separated the territory from both provinces and constituted it as a province, to make the people happy and voted for unification with Nigeria. The Sardauna considered this from a wider perspective because he considered the whole of the northern Nigeria, as his constituency and therefore felt that there was a need to get back the territory. After the 1961, Dikwa Native Authority moved from Sardauna province to form part of Borno empire.

But the premier objected the demand by some non-Fulani ethnic stock in Adamawa province for separation from the Adamawa Native Authority. ${ }^{35}$ Perhaps, these ethnic groups could be the minority who were against the unification with Nigeria, who were said to be in fear of yet another Fulani domination rule.

\section{The First and Final Plebiscite Unification Process}

As earlier indicated, the administration and development of this territory were done along with Northern Nigeria. As a result, the economic and social service of the people was also done along this time and within the same context, including the political progress of the area took place within the same framework and in the Nigeria colony. It is interesting to note that the representatives of the territory in the Northern Nigeria House of Assembly and House of Chiefs were the spokespersons of the territory. The former representative included among others the Minister for Northern Cameroon Affairs, Alhaji Abdullahi Danborom Jada, the then chairman and aristocratic Fulani by birth and Fulani from Adamawa, Southern part of the territory, the chairman of the consultative committee for the Northern Cameroons, Alhaji Abba Habib a Kanuri from Borno, Northern part of the territory. These meaningful individuals were among those that advocated for the unification of the trust territory with Nigeria. ${ }^{36}$

However, the result of 1959 Plebiscite shows that views of the representative of the so-called people of the territory were not the wishes of the people who were supposedly been represented. The plebiscite did under the careful supervision and close collaboration of the United Nations and the British colonial Government. The plebiscite organized in a very simple very free and fair voting. There was an organized campaign on how to vote, the most organized one was the film that was introduced by the Northern Nigeria information service which demonstrated to the eligible voters how voting should take place during the plebiscite. Three languages were used on the film, Fulani, Hausa and English, this was to make sure that nobody was left and perhaps to avoid been accused of any possible bias in the voting. Dr Jalal Abdoh was the commissioner, who was appointed for the assignment in the meantime, Abdoh, choose Yola the Plebiscite headquarters for the 1959 Plebiscite, Sir, John was the Plebiscite administrator in Togo land for the 1956 Plebiscite. ${ }^{37}$

Abdoh and John took various tours of enlightenment that took them to different parts of the territory to make sure that all was well and set for voting. Sir John had under him three assistants, each appointed for Mubi, Bama and Jada; these people were engaged in the preliminary organization of the plebiscite. All drawn from the Civil Service of Northern Nigeria. The administrator undertook a tour on his own occasionally and by so doing, nine additional returning officers and centres established for another District. The large district for Adamawa south had two returning officers Sarti had one who was in charge of the plain, while the one for Gembu covered the Mambila Plateau ${ }^{38}$.

The plebiscite administration in conjunction with the Nigeria regional government deployed about one hundred and forty-seven Nigerian police officers to the territory. Now with all these arrangements put in place for in preparation for voting by mid-November 1959, the General Assembly recommended the following question:

Do you wish the Northern Cameroons to be part of the Northern region of Nigeria when the Federation of Nigeria became independent? Or Are you in favour of deciding the future of the Northern Cameroons at a later date?

However, voting took place in a peaceful manner, with a minimal hitch from the political parties, especially during the campaign period. The arrangement for the party representatives was abundantly clear by the plebiscite the Nigeria authorities entrusted in the army and the Federal Department of telegraphs the responsibility of transmitting the result in good time, in this connection, telegraphs, installed at each of the voting stations. This included Mubi, Jada Sarti, Michika, Bama, Baisa, Dikwa, Gwoza and Gembu. The reason for this was to make it fast, that result sent to Yola with a minimum delay. In addition, the post and telegraph departments also set up radio-Telephone apparatus at Bama, Gwoza and Mubi which communicated with Maiduguri and Yola, thence Kaduna to maintains law and order during the exercise. The administrator, the authority conferred on him and the commissioner, announced the result on the 10th November 1959 with the following results. 


\begin{tabular}{|c|c|c|c|}
\hline Plebiscite & Vote for Nigeria & $\begin{array}{c}\text { Vote for } \\
\text { Cameroons }\end{array}$ & Total Votes \\
\hline Dikwa North (Bama) & 7,575 & 7,197 & 14,772 \\
\hline Dikwa central & 8,891 & 11,988 & 20879 \\
\hline Gwoza & 3,336 & 6773 & 10,109 \\
\hline Modagali/Chubanawa & 4,247 & 9818 & 14,065 \\
\hline Mubi & 6,120 & 13578 & 19,698 \\
\hline Chamba & 4539 & 11651 & 16,190 \\
\hline Tongo/Gashaka & 2252 & 2099 & 4351 \\
\hline Mambilla & 2745 & 7353 & 10,098 \\
\hline United Hills & 3063 & 89 & 3152 \\
\hline Total & 4,2788 & 70,546 & 113,334 \\
\hline
\end{tabular}

Table 1

Source: Trusteeship Council/Report 1959 Plebiscite

In accordance with the plebiscite regulation of Northern plebiscite of 1959. Section 10(2) of the same regulation. The political parties could appoint this agent on the polling stations for detecting any possible fraud during the voting exercise. The major political parties were (NPC, Northern People Congress (AG) Action Group, (UMBC), and United Middle Belt Congress and (NCDP) Northern Cameroon Democratic Party. Among all the political parties, only the NPC, which was the ruling party of Northern Nigeria, was in favour of the first alternative. The remaining parties were all in favour of the second. Each of the political parties appointed one polling agent for each polling stations for which it wished to represent. Thus, brought to four pulling agents per station. These political parties translated the alternative into Fulani and Kanuri languages. They maintained that with the territory been controlled by the Adamawa and Borno province, unification with Northern Nigeria amount to the minority groups remained permanently, under the rule of the Fulani and Kanuri. Very active among them was the NKDP, which pushed hard and vigorously campaigned within the minority ethnic groups of Mubi hill pagans, Michikaand Mambilla, Plateau, ethnic tension became dominant after 1959, Plebiscite because most of the people that voted for the second alternative were the minority pagan groups. Notwithstanding the outcome overwhelmed more especially to the ruling (NPC) Northern People's Congress.

However, by these results from the table (1) above shows that the total votes of about 113,334 a reasonable number of about 70,546 voted against 42,788. By this Plebiscite, the result indicates that most of the people not in favour of the first alternative, therefore, voted for the second alternative. The implication of this was a concentration of the territory under the trusteeship. Not only that women not given the right to vote only a male adult, was by law allowed to vote. The outcome of the plebiscite was a great blow to the especially ruling party, who was confident that the results of 1959, a plebiscite would be in their favour.

Nevertheless, turned out be the reverse, barely, three days after the plebiscite the three political parties, whom the second alternative went for, waged a serious campaign among the pagans who voted for the second alternative. One of the reasons why the outcome was a surprise, because, in one of the visits of the United Nations Visiting Mission, that visited the territory on an administrative survey in 1959, made blatant mistake and had a discussion with only the dominant Fulani and kauri rulers. They never had a talk with any groups or individual to ascertain the situation of things. Instead, they went back with the impression that unification of the trust territory with Nigeria was almost unavoidable. It would be recalled that both Habib and Danboram Jada gave the same impression to the visiting mission. In this regard, the members apparently failed to consult with the politically submerged, but numerically superior pagan populations in the plains and the hills. None of the opposition parties consulted by the members who claimed to be representing the interest of the minority groups ${ }^{39}$, the minority pagan had all these periods harboured long-standing grievances against the Fulani and the Kanuri rulers; especially the Fulani who enslaved them seized their farmlands, converted some into Islam by the sword, thereby chased many and restricted them to the hilltop. As we have seen, the colonial government with their policy of indirect rule system had strengthened the pre-colonial political and social system that left these minority extractions under the rule of both the Fulani and Kanuri.

Therefore, the outcome of the plebiscite clearly shows the discontent and reaction of the minorities the domination power of the Fulani and the Kanuri, during the pre-colonial structure through the Native Administrative system. Sir Andrew Cohen, a onetime British Official at the United Nations, who in his mind had a requisite perception towards the plebiscite, explains it as a reaction against some abuses, he says:

Whereas the premier of Northern Nigeria, who was also the National Leader of the NPC, erroneously attributed them to 'subversive activities of the British officials. Thus, the negative outcome of the plebiscite suggests that the position that the people took to stay clear from the unification process originated not from grievances they had with the Northern Regional Government, but rather with their dissatisfaction with the system of administration of Adamawa Native Authority. On the contrary, the result of the plebiscite of 1961 shows that the people were ready to remain in Nigeria so long as they were allowed to form Native Administration of their own of the independent of Adamawa and Borno States. ${ }^{40}$

Yet another explanation during 1959, plebiscite results had to do with the inclusion form of the second alternative made it possible for the opposition of those favoured the first alternative that is NPC Adamawa and Borno native Authorities, to focuses their campaign on local issues. Such issues as noted differ from one place to another. For example, it objected for control from Yola, and the Fulani ruling class in Chamba of Ganye areas mainly supported the campaign. It became clear the Native Authority, while in the Mamibilla Plateau, it objected to remote from Yola, with underlying 
hostilities of the former for grazer, who it seemed, protected a contest between the Chamba and the Fulani ${ }^{41}$. In Borno, it objected to control from the Kanuri over Gwoza people ${ }^{42}$.

Probably, one of the factors that regard the resistance to the political and social set up was because of western education, though western education came rather late notwithstanding, it nevertheless had repercussion on the people. In 1938, Sudan Mission was introduced, the Christian Missionary Organization established a primary school in Gwoza. In 1942, they moved to Shuwa, Michika areas, and opened yet another school. This followed by a Bible School opened in Mapeo, Sugu and Dashen in 1946, all within the Chamba region. This organization became known as Lardin Gabas. ${ }^{43}$ In addition, the colonial Government built six primary schools in the territory from 1949-1959, which was situated in the minority areas. As a result, many ethnic groups began to challenge the traditional rulers' position, thereby considered it illogical. The NKDB emergence was behind such an organized behaviour of the ethnic minority towards the traditional institutions. The educated elites of Madagali and Michika Districts formed this organization, with followers all over the territory. As indicated earlier, the party played a position of dominance role in determination of the plebiscite result of 1959.

The acceptance of western culture by the pagans, became a matter of concerned to the ruling - class; it was considered that pagans were far superior, numerically, to the Fulani and Kanuri rulers. While it was a political significance for the pagans, but for the Kanuri and Fulani, it was a serious concern and minus to the rulers. ${ }^{44}$ The reason why the Fulani and Kanuri saw it as a threat, Perhaps, if the pagans allowed themselves to be used the franchise available at their disposal, the Fulani and Kanuri, domination in an elective position, particularly offices would have been loomed. The relegation of the interest of the local ruling class became clear after the plebiscite of 1959. As a result, the Northern Regional government launched a vigorous campaign and brought about a radical change in the administrative setup, in preparation against the final plebiscite of 1961. When the people of the territory would decide whether to join the independent Republic of the Cameroon or independent federation of Nigeria.

Moreover, with the Nigeria federal elections expected about the same year, the plebiscite was a crucial matter particularly to the NPC, ruling party. The reason for this was that, if by any chance the territory voted against joining the Federation of Nigeria, the region would lose the seven-sits they had in the federal legislature. This made NPC double their efforts towards the two elections especially the plebiscite, which held earlier than the federal elections. The regional government expected that local branches of its party in both Adamawa and Borno to handle the plebiscite effectively; the plebiscite result jolted the government out of complicacy and made to realize that the problems were too complex. It found out that the local party members were not capable of solving the problems and that in fact, they were part of the problem. ${ }^{45}$ Therefore, they decided to deface them at least on the peripheral basis, for the second attempt of the plebiscite. For this reason, Danborom Jada was removed and replaced by Mamman Bashar as Minister for Northern Cameroon affairs. Bashar a Hausa by birth, though a Fulani member of the aristocratic class and was the Emir of Daura, he was considered probably, because of his neutrality and an outsider. Muhammadu Ribadu, an influential Fulani politician from Adamawa was not initially involved in the campaign but participated in the planning and strategies. ${ }^{46}$ Britain and United Nations organization, in consequence of the 1959 plebiscite, the regional government on the recommendation of Britain and the United Nation set up a commission of inquiry, known as Mohammed Tukur commission of inquiry. The purpose of this commission was to consider new administrative setup and reorganization. The commission was to look for ways: that would allow for greater autonomy to the people in the territory at the local level. ${ }^{47}$

With this new arrangement, the government seemed to recognize the subservient position of the local people to both Adamawa and Borno potentials. This led to a radical change in the administrative structure, in 1 stMay, 960 , the territory became a province, known as the Northern Cameroun province, be administered by the European provincial commissioner, Sir, E.D Muffet. Two new proveniences created within the province with an additional six new Native Authorities. The two divisions were the southern Trust Division, which consisted of District of NassarawoYelwa, SuguTongo all within the local problem area during the plebiscite that is (Chamba area) Gashaka and Mambilla. With Headquarters of the division at Ganye, but temporary at Jada. The North Trust Division consisted of the Districts of Mubi, belel, Chubanawa, Bama, Gwoza and Madgali, with headquarters at Mubi, and the principal headquarter. The six native authorities were Chamba, Gashaka/Mambilla, and United Hill subordinate Native Authorities: Mubi, Gwoza and Bama48.

More so, these, a new policy also introduced; all village heads were to be elected (among members of the aristocracy) and not appointed as was hitherto. The unpopular court based on (Siyassa) in the southern division was abolished, thereby, replaced by Sharia courts in which non-Muslims, for the first time had access for representation. ${ }^{50}$ The reason was to remove the ethnic tension, and partly for administrative convenience. The government in its continued efforts to make things work abolished the Cameroon consultative committee, which was headed by Abba Habib and replaced by an advisory committee, with members drawn from the newly created native Authority councils of the territory. By these arrangements, Habib sized to be an active member, especially in the affairs of the Northern Cameroons. The responsibility of this rested on the premier and his office, this means that he was in charge of all executive matters of the province, with Sir, Muffet played the role of Administrative officer and provincial commissioner.

Certainly, the regional government had dealt with the problem directly.

Ardo says:

the premier himself saw the incorporation of the Northern Cameroun to the north as a personal challenge Beside the administrative setup, and a way to entice the people perhaps to vote in favour of Nigeria, the government established more hospitals in the province, in fact, it became the only province that had such a number of hospitals and equipment's. Those benefited were Ganye, Mubi and Bama with well-equipped hospital required. In addition to these, thirty-four-bed space missionary hospital at Gwoza. The period from 
1959-1960, witnessed for the first time in the history of Vere and Fali areas, had schools and post office at $\mathrm{Mubi}^{49}$.

In line with political parties' guideline, the campaign allowed for all the major political parties, prior to the plebiscite, after the United Kingdom administer had concluded his public enlightenment campaigns informing the people about the unification of the territory and the implication of the alternatives. However, in the campaign that ensured all the political parties, presented their main objective and reasons why the territory be unified with Nigeria. The political parties involved were the Northern People's Congress (NPC), the Nigerian Element Progressive Union (NEPU), the Action Congress (AG), and the United Middle Belt Congress (UMBC), with the two alternatives question:

Do you wish to achieve independence by joining the independent Federation of Nigeria? Or 'Do you wish to achieve impendence by joining the independent Republic of Cameroon?

The political parties involved, relied at almost on words of month campaign speaking through the local chiefs and leaders. The reason was that the leaders were so powerful that, which their subject hardly went against their orders. Moreover, possibly, the only way the parties saw there would succeed. 'The Nigeria consortium, working unofficially through the newly created native authorities stressed the advances made under Northern Nigeria Government'50.

The politicians reminded the people of the territory of its 'historical traditional economic and administrative ties with Nigeria, and of social ills that would follow in the events, the people opted to join the Republic of Cameroon. Such as official language, education systems, monetary system, weight and driving on the other side of the road and most of it all a complete over the whole of the newly created administrative structure, which put in place. In the meantime, within the consortium, each party aimed at discrediting the other during their campaign to enable it to win support and get more votes.50thismay be regarded as a typical party's consortium character. Not only, which the two Cameroon parties also united in their choices. Certainly, it was because of this choice that the Cameroun Patriotic Front (KEP) broke from the Action Congress (AG) the party (operated mainly in the Chamba and Gashaka/Tongo District) and the (NKDP) (with uncertain members and sympathizers among the hills pagans in Chamba, Madagdi and Michika Districts) advocated for unification with the Republic of Cameroon. These were some of the minority ethnic areas discussed who were not in favour of unification with Nigeria, because of what they termed Fulani and Kanuri domination and miss-rule.

However, in less than two years from the first plebiscite in 1959, the people of the territory for the second time witnessed against yet another plebiscite in 1961, for the people of the territory to decide the nationhood. All arrangements concluded as easily as (7:00 am) seven in the morning, people came out very early, in fact as early as (4:30 am) four-thirty in the morning in response to a request 'to came early and avoid the rush'. ${ }^{51}$ This time around women could vote along with men. In fact, it was the first-time women could cast their votes in the history of Northern Nigeria. Pulling stations mostly situated in schools, courts and office premises that known to the people. The rooms and the plebiscite staff, and the voting booths were fenced to keep the people from a distance. They constructed in such a way that a single queue formed to make voting easier. each voter presented his/her voters registration cord, had the name-checked to confirm voter's registration from the list in the presence of all the representatives of the party and other officials after that the voter had the right thumb dipped into indelible ink to avoid double voting) the voter was given ballot paper and lastly sent to the booth, there were two boxes provided one Green and the other White ${ }^{52}$. If wishes to vote for Nigeria, the voter placed the card in the green box, and if wish to join Cameroon to use the white box ${ }^{53}$. Apart from the voting tension that usually connected with elections, the voting went on smoothly; the plebiscite administrator as below thereafter realized the results.

\begin{tabular}{|c|c|c|c|}
\hline Plebiscite & Vote for Nigeria & $\begin{array}{c}\text { Vote for } \\
\text { Cameroons }\end{array}$ & Total Votes \\
\hline Dikwa Northern (Bama) & 22765 & 10562 & 33327 \\
\hline Dikwa central & 28697 & 24203 & 52000 \\
\hline Gwoza & 18115 & 2554 & 29672 \\
\hline Modagali/Chubanawa & 16904 & 13299 & 30203 \\
\hline Mubi & 23798 & 11132 & 34930 \\
\hline Chamba & 9704 & 23177 & 34881 \\
\hline Tongo/Gashaka & 4999 & 3108 & 8107 \\
\hline Mambilla & 13523 & 7467 & 20,990 \\
\hline United Hills & 7791 & 157 & 7948 \\
\hline Total & 146,296 & 47,659 & 243,958 \\
\hline
\end{tabular}

Table 2

Source: Plebiscite of 1959/1961 United Nation Doc. T/1491

The commissioner for the plebiscite report to the trusteeship council acknowledge, and accepted 1961 in respect of both Southern and Northern Cameroons as follows:

I am satisfied that the people of southern Cameroun had the opportunity to express their wishes freely and secretly at the polls concerning the alternative offered in the plebiscite. 54

The report starts again:

While the majority of the people may not have grasped the detailed implication of the alternatives at the plebiscite, it can confidently be said that they were aware that the decision they were called upon to make meant joining one or the other of the two neighbouring Counties. ${ }^{55}$

Concerning Northern Cameroon, the commissioner says: 
... although the majority of the people of Northern Cameroon may not have grasped the intricate and complex constitutional implication of the two alternatives, they were aware nevertheless, that the decision they were called upon to make at the plebiscite meant joining one or two neighbouring countries... 56

The plebiscite efficiently organized and conducted by the administrating authority in accordance with the legislation promulgated for the purpose. In spite of the defects and weaknesses inherent in the situation prevailing in Northern Cameroon, I am satisfied that the people had the opportunity to express their wishes freely and secretly at the polls, concerning the alternatives offered in the plebiscite.

However, in careful observation of the plebiscite indicates the pagans who again tipped the voting balance, but this time in favour to join Nigeria, the results, shows that only one constituency was a majority in favour of Cameroon. During the political party's campaign, especially the NPC, the use of threat on the pagans, it is rather difficult in view of the peculiarity of the territory to assess victory in terms of campaigns of a political party. Nevertheless, certainly, the achievement could no doubt be attributed to the various reforms undertaken after 1959, lost plebiscite. On top of this could have been the commitment of the Northern Government to maintain the territory as an independent province might have contributed to the wining of the votes.

The reaction of the government of Cameroon on the outcome of the plebiscite was that foul play was committed thereby falsified the results. ${ }^{55}$ The Cameroon Government immediately lodged a complaint to the United Nations Organization to that effect that the plebiscite did not represent the wishes of the people of the territory. ${ }^{57}$

In a letter of the petition to the United Nations, the southern Cameroun Government accused both the administering organ, Greece, Britain and the United Nations itself, including the supervisory term, had permitted irregularities both during the registration of voters and during the conduct of the plebiscite up to the counting of the ballots. Nigeria accused to have sent quite a number of police officers before the plebiscite. Ostensibly to intimidate the voters or as it were 'to vote at the pointed bayonet'. ${ }^{57}$ Now the complaint was sent to New York. The British Government, after carefully studied the petition denied the allegation, Dr Abdou, who was the commissioner reports that:

The registration itself was well conducted over the whole of the period. With the vigilance of registration officers and the United Nations observers, who were normally assigned to oversee the personnel in three to five registration areas, most of such minor errors such as the omission of names and faulty serialisation of registration numbers were corrected. ${ }^{58}$

The British on its part further denied that 'electors likely to vote for reunification with Cameroun were systematically left off the registers' and the Innuendo in the statements that this was done by the chiefs' faithful to Nigeria'. Further, Dr Abdou points out that an assistant registration officer who recruited for that assignment carried out the registration of voters. He again reports:

To carry out registration of voters in the 346 registration areas of the Northern Cameroons the administration required a total of 430 Assistant Registration Officers. These officials were recruited from within the Trust Territory with the exception of twenty-five student of teacher Training College Numan which is situated in Adamawa province in the Northern Region, but it is worthy of note that half their number were indigenous to the Northern Cameroons. The assistant registration officers were recruited from the various education establishments inside the Territory including the Staff and pupils of the Teacher Training College Baisa and Mubi of the senior primary schools, and teacher from the various Native Authority and voluntary agency. ${ }^{59}$

He also adds that:

Since it was the first time that women had been given the right to vote in the Northern Cameroons, the administration made every effort to recruited suitably qualified women to serve as assistant registration offices and thus to lend encouragement to potential women voters to came foulard to register. A total of twenty-five women served as registration officials in the various districts in the Northern Cameroons, and the United Nations observers and Administrative Officials alike attested to their efficiency and effectiveness. 60

However, apart from the allegation brought by the Government of Cameroons, other political parties in favour of unification with Cameroon also lodged a complaint. Their complaints included among other things, discrimination and imprisonment of the supporters of NKDP/KEP. Especially KEP, whose president was Mallam Umaru Michika, (a party favouring union with the Cameroon Republic) alleged that prison filled with people because of their political associations. On this, he was asked to visit the prison and mentioned those that he thought been jailed, when he visited the jail in Mubi, he brought about seven names, and another unmentioned person added other names. This brought the number to 12 twelve names. Uniformity, only seven-person was listed in Dr Abdou's report which had arisen from offences. Dr Abdou points out that though the person charged with one offence or another had the right to be represented by a council of his choice; this ruled out because there was no provision existed for the appearance of defence lawyers in Native Court procedure. In yet another development, a thorough investigation carried by the United Nations Liaison officer at Mubi together with the MallamYaro, the Representative of Government of Cameroon, who visited the jail in Mubi only fifteen cases recorded in the relation of offence regarding connection with political meetings based on the interview of the prisoners. Regarding this case, Abdou again reports:

According to the report of the senior District officers upon conclusion questioning, MallamYaro expressed himself as being satisfied that the persons concerned had been imprisoned on reasonable and legitimate grounds and only requested that the four prisoners awaiting trial be brought before the courts as soon as possible. This, the senior District officers assured him, would be done. MallamYaro also warned three of the prisoners he had seen that since the permit was required to hold political meetings, they should have 
observed the law. He told them that similar laws in respect of meetings existed in the Republic of Cameroun and asked the three prisoners concerned to convey what he had said to the other prisoners. ${ }^{61}$

However, the entire allegation, by the Cameroon Government, and the people referred to in the report had investigated by the plebiscite commissioners. Similar reports submitted to the United Nations observer at Mubi. In the report, 58 fifty-eight people were recorded in various ways, eleven names were duplicated, eight was nowhere to be traced, ten were released on bail before the plebiscite, seven had no political significance, one appeal was dismissed, one allowed, four awaiting appeal, and fifteen did not appeal. During the period of the plebiscite, it discovered that about twenty people were in the prison in Mubi, out of this number, seven on conviction with no political significance. The complaint of the arrest came almost entirely from the Madagali, Michika and Mubi districts of the Mubi Native Authority where the parties favourable to unification with the Cameroon Republic. In yet another arrest, on 29 January 1961 thirtyfive people arrested, out of the total, four were imprisoned and the rest fined in accordance with the law.

However, about the allegation on the freedom of speech, Dr Abdoh, commissioner for the plebiscite, stipulate in his report that the Native Authority on Public assembly usually used such permission unless otherwise, there was a likelihood of a breach of peace, then it denied. Abdoh reports:

There continued to be a few instances in which permits were refused some time for valid reasons e.g., to hold meetings on markets days in or near the marketplaces. In addition, a few permits were refused because the applications were either Vague or contained request for meetings to be held on more than a day. In those cases where the reasons for the refusal were different from those set out in the proclamation, representatives were made and usually, following an investigation, the permit was granted. ${ }^{62}$

Furthermore, the complaint about the general question of restriction within and out of the territory, the committee maintains that:

... the United Nations Liaison officer, in Mubi for his part reported that he had passed through the frontier between the Territory and the Republic along the road from Mubi to Garua on at least six occasions, and that he had visited the border on at least four other occasions, and that he had not noted any police officers or authorities posted for the purpose of stopping vehicles on the road from Mubi to Garua. Neither I nor United Nations officials who travelled rapidly on the road from Mubi to Garua found a checkpoint on the Northern Cameroons side of the border. ${ }^{63}$

The Republic of Cameroun in yet another allegation on 1961, Plebiscite, accused the Regional Government of Nigeria and the commissioner for intimidation and employment particularly, the employment of expatriate staff. The commissioner for the Plebiscite as contained in the Plebiscite report denied this. The commissioner Dr Abdoh, responded, as regards the ledged employment of the expatriate staff, his report:

As regards expatriate staff, it would have been in the administrator's view wholly impracticable to bring the territory and to employ in its administration expatriate officials from the United Kingdom or from British territories who were neither acquainted with the problems of the area nor able to communicate with the local people in the local languages. It was for these reasons that the administering authority decided to retain on a secondment basis from the Northern Region Government the services of such numbers of officials (British as well as Nigerians) as were required for the administration of the Northern Cameroons. This numbers, although limited during the period when the Territory Region Government. 64

It was inevitable that the links of the above officials with the Northern Region Government, which most of them had served for some years past, as well as their own sympathies towards Nigeria, would open the door to suspicion of partiality and become the subject of bitter complaints from the parties, which favoured union with the Republic of Cameroun. However, no specific evidence of impropriety brought to light.

Furthermore, the allegation on the Arabs of Bama also denied that all the parties in accordance with voting regulation and procedure applied or adhered. On the issue of security, the government of the Republic Cameroun alleged that barely three days to the voting, a total number of seven hundred police officers brought into the territory for the Plebiscite, in addition, an unspecified number of 'troops' also used according to the allegation put forward by the Cameroons. In response to this allegation, Dr Abdou mentioned that only fifteen policemen were brought into the territory during the 1961 Plebiscite, that now brought to a total number of about (172) one hundred and seventy-two for the whole of the Northern Cameroons.

For the military, according to him only those of the detachment 101 signal that used for voting and counting for both 1959 and 1961 Plebiscite, and they had not been allowed to carry any arms they further aligned continued that extension was allowed instead of one day. In his response, the commissioner explains that:

In order to enable the largest possible number of inhabitants, particularly the recently enfranchised women to participate in the Plebiscite and wishing to avoid the introduction of polling staff from outside Trust Territory, I agreed to the extension of the polling period from one to two days, provided that the Plebiscite Administrator could assure me concerning the safety of the ballot boxes during the right separating the two polling days. The assurance was subsequently given to be entirely satisfactory, and the Plebiscite Administrator designated 12 February 1961 to me be additional polling days. 65

However, in addition, the polling both constructed to a standard in such a way that no police officer or any other official inside the polling station. But where it became necessary that a policeman was needed in the station, (Northern Cameroons) police were allowed, as happened in one or two instances, but not the police from the Trust Territory, this is the (police on loan to the Trust Territory Administration and under the Authority of the Administrator). As indicated in the whole of Northern Cameroon there was about 391 (167 Nigerian police hired for services in the Northern Cameroons, 45 in the Native Authority police training unit and 179 other authority polices the latter 224 were Northern Cameroons). 
The number of police officers indicated covered about 378 polling stations, based on this the commissioner and the region, the British completely denied the allegation by the Republic of Cameroun on the excesses of police officers provided for the Plebiscite. This according to the commissioner, even if there was such a number as alleged by the Republic of Cameroun, they would have been quite impossible for these to have exercised a significant influence on the 378 polling stations. Dr Abdou puts:

A total of 760 presiding and polling officers were recruited from within the Northern Cameroons, with the exception of twenty-five students from Numan Teacher Training College Adamawa province of the Northern region of Nigeria. Some were residents of Northern Cameroon. Although I have had requested the administrator in so far as possible to recruit staff from among qualified persons in the Northern Cameroons. I raised no objection to the employment of these 25 students because these men's previous experience and their knowledge of the difficult Mambilla Plateau could most usefully be employed during the polling period. The presiding and polling officers were recruited from among senior and Junior School Teachers, missionschools' teachers and pupils who had completed standard IV or above. Training courses were held at each of the returning officers' headquarters, lasting over periods from eight to nine days. These courses were begun on 28 January and lasted until 6 February. During the training courses, these officials were instructed in the instruction of polling stations, the mechanics of polling and their duties concerning the delivery of ballot boxes to the counting centres and were issued written instructions. ${ }^{66}$

However, it pointed out that no press allowed to speak to anybody or allowed to go into the polling station with a view to confirming whether the boxes were empty before the Plebiscite. Perhaps, contribute the reason for these to the fact the press representative was of the Republic of Cameroon and were active members of the campaign who also favoured union with the republic. For the Plebiscite be credible, there was need to keep the secrecy of the poll, because of this not even the Plebiscite officials and the United Nations observers and the polling agent who was appointed by the parties were allowed into the booths'. The United Nations Plebiscite Commissioner has this to say:

However, I agree to the administrator's suggestion that each of the two-government concerned is invited to designate six press representatives to come to the territory to witness the polling and counting of the ballots. Accordingly, individuals were sent by the administrator to both Governments and so far, as I am informed, the Republic of Cameroun sent one representative to each of the areas in which a counting centre was located. The Government of the Federation of Nigeria for its part limited itself by sending a few cine cameramen and photographers to the territory. ${ }^{67}$

Further, to avoid any kind of accusation, the two ballot boxes placed in a direction that was to be seen by all voters, and in clear and safe location. The commissioner again describes this in his words:

During the course of training, polling staff were instructed in the construction of polling stations and each was provided with a construction plan which required that the stations were built on an axis between the borders of the Republic of Cameroons and the Federation of Nigeria and that the ballot boxes were placed in the respective directions. In this way, a total of 378 polling stations were created in the 246 registration areas of the Northern Cameroons in locations which had previously been cited by the returning officers. The polling staff was also provided with all necessary equipment called for regulation 7 , before being sent to their stations. 68

However, in the whole of the Northern Cameroun Plebiscite, only one report of the closure of polling station received. The polling station at 2a closed down because of a disturbance that occurred. The reason was that the presiding officer had allowed polling agents into the booth. There was also an alteration regarding some ballot papers, which said not placed in their respective boxes. This led to a disturbance which vandalized the polling station. In view of this, a fresh election was organised and was completed on the 13th of February in accordance with the Plebiscite regulation. We may assume that this was the only incident of such in all the territories or rather the polling stations.

However, at the end of the polling, counting of votes begun and was completed within three days, in southern Cameroun where no complaint was made took four days to accomplished counting. Now regarding the counting of the votes, Dr Abdou comments:

...only the returning officers and the United Nation observes were in possession of the codes and knew the number belonging to a particular polling station. The counting agents, although able at all times to satisfy themselves of the accuracy of the count, could not identify a particular polling station as such, during this procedure the counting agent was located at a point close enough to them to observe the coding operation by the returning officers and the United Nations observers, ballot close enough to be able to identify the code number with its polling station. Once the foregoing operation was completed, the opening of ballot boxes, the counting and all other procedures were fully witnessed by the counting agents. 69

Now, concerning the actual counting of the ballot papers, some officials selected for the important assignments. Dr Abdou points out in line with his selection procedure, that:

...those selected for this important function had for obvious reasons to be selected from amongst nonCameroonians. Also excluded by common consent were those officials who were primarily charged with the administration of the territory. In the circumstances, the field of choice was narrowed to technical or contract officers and their wives. At one counting centre, for example, the counting officers included Priest of the Roman Catholic Church a Nursing Sister, two professional engineers and a Doctor of Medicine. ${ }^{70}$

On the conclusion of the count, the British government relied on Abdou's report, found the Plebiscite to be credible and therefore considered it as contained in the report of Dr Abdou it reads: 
...although the majority of the people of the North may not have grasped the intricate and complex constitutional implication of the two alternatives, they were aware, nevertheless, that the decision they were called upon to make at the Plebiscite meant joining one or other of the two neighbouring countries.... The Plebiscite was efficiently organized and conducted by the administering authority in accordance with legislation promulgated for the purpose. In spite of the defects and weaknesses inherent in the situation prevailing in the Northern Cameroons, I am satisfied that the people had the opportunity to express their wishes freely and secretly at the polls concerning the alternative offered in the plebiscite. ${ }^{71}$

However, based on Dr Abdou's report, British Government submitted the report on April 21, 1961, The United Nation in its meeting of General Assembly rejected the Republic of Cameroon's complaints and ratified the plebiscite results. Thus, the Trust Territory formally unified with Nigeria, around June1, 1961. the handing and taking over of the territory took place in Mubi, in a low and dignified ceremony when the Northern Cameroons was formally handed over to Nigeria, to become the 13th province of the Northern Region.

The representative of the United Kingdom, who was also the administrator of the Trust Territory Sir, Percy HymHarris, handed over the territory to the Prime Minister of Nigeria Sir Abubakar Tafawa Balewa, the Prime Minister of Nigeria, before large crowd in Mubi. It became the second smallest province of Northern Nigeria, after Kabba province with an estimated population of about (17000) seven thousand inhabitants then. A council of ministers meeting held in Mubi as suggested by then chief of Mambilla, AlhajiMohammad Mansur, the province named Sardauna province. By this, the territory lost its identity as the former United Nations Trust Territory for Sardauna province and became fully a Nigerian region.

\section{Conclusion}

This article examines the British occupation of the former United Nations Trust territory in Northern Nigeria, with a view to examining the political transformation of the Trust territory from the period of 1945-1961. As a precursor to the study, the final unification of the Trust territory with Nigeria in 1961. Similarly, it examines how the minority ethnic extractions exploited by the European powers through the Fulani and the Kanuri rulers, who owed their position to the $19^{\text {th }}$ century Jihad. The minority extractions belong to the various indigenous ethnic groups who were mostly non-Muslims as we have seen. During the period, the Fulani and the Kanuri Aristocrats ruled over the people. The territory then was a German-Cameroons, which came under British through their indirect rule system, the adoption and experimenting of the system in Northern Nigeria came any significant or meaningful changes in the territory.

However, the British as part of the deal, bent on making sure that the mandated territory unified with Nigeria. In line with this, the British championed the political ties of the territory with northern Nigeria. It was this and other historical factors, within the territory that brought about an easy unification of the territory with Nigeria. The minority ethnic groups who hitherto opposed the Fulani rule and the Native Authority Government and perhaps, the oppression and injustices as claimed, voted against Nigeria in the first plebiscite of 1959. The Regional Government of Northern Nigeria knowing fully well, what happened in the first plebiscite of 1959, took steps and made some changes in the administration settings. Consequently, in the February 1961 plebiscite, mass votes for the unification with Northern Nigeria. More especially, the influence of $19^{\text {th }}$-century jihad before the unification process without which would have been rather difficult in a region where most of the people were non-Muslims. Undoubtedly, before the plebiscite, almost all the rulers of the territory accepted Islam, with the minority ethnic groups escaped for fear of been involved in the jihad, thereby restricted themselves to the mountaintop.

\section{References}

i. Ardo u, northern Cameroon: the aftermath of incorporation into Nigeria 1960-1983 dissertation m.a university of Maiduguri, 1990. P. 292

ii. Ibid. Pp. 64-107

iii. Ibid.pp. 100-210

iv. Abdullah, r. D., Nigeria-Cameroon border relations. A study of bakassi crises msc dissertation, university of Maiduguri Nigeria, 1998. P. 78

v. Ardo u, northern Cameroon: the aftermath of incorporation into Nigeria 1960-1983, pp. 120-287

vi. Abdullahi a. Gwoza during colonial rule, b.a. project university of Maiduguri, 1984.

vii. Abubakar saad, the emirate of fombina: the attempt of a politically segmented people to establish and maintain a central form of government, PhD thesis Abu Zaria, Nigeria, 1973.

viii. Ahmadu, u. J. The failure of radical politics in northern Nigeria, university of Edinburgh msc thesis, 1975.

ix. Ahmed, a k, late alhaji the right honourable sir $m$ a thesis, tafawa balewa university bauchi, 1984.

x. Abdullah. A. I, gwoza during colonial rule, 1984, p.63.

xi. Borno province of Nigeria annual report 1934 (nak) acc no. 1756.

xii. Abdallah d. R. Nigeria-Cameroon border relations. A study of bakassi crises. Pp.72-82.

xiii. Lugard, annual reports, 1906 national archive kaduna (nak)

xiv. Palmer,h. R. Borno province- resident, report national archive kaduna no. 68, for the year ending $31^{\text {st }}$ December, (1923), national archive kaduna (nak).

xv. . Eustace r. B. B (1939) 'report on hill-pagans of gwoza and ashigashiya, 'f. No. 414(tcl) gwoza, nak.

xvi. Gavin r. J and betly j. A (1973) the scramble for Africa, Ibadan university press. P.12.

xvii. Synder g. (1977) conflicts among nations, bargaining, decision-making and system structure in international crisis, Princeton University press New Jersey, 1977, p.89. 
xviii. National archive kaduna (nak). B.m. macfarlane, 'report on gwoza and ashigashiya hill-pagans' no. 229(tcl) gwoza, 1958.

xix. Mubi tradition, 1967

xx. F.o. 84/2109, MacDonald's report on the administration of the royal niger company (rnc) library abu no. 1890 nhrs.

xxi. The gongola state of Nigeria, gazette, no.34 volume.6 (gg.s. law no.5 local government edict, 1977, gazetted, 1981 .

xxii. 'tarihiaddininmusulunci' mubi file no. 28. Aliyu a.y. koehn p.h and hay r. Pp. 16-17.

xxiii. Kirth, panter-brick 1978) soldiers and oilthe political transformation of Nigeria. Frank lass and co. Limited, London, 1978, p.156.

xxiv. Temple oliver: notes on the tribes, provinces, emirates, states of the northern provinces of Nigeria, ed, c l temple, lagos press, 1922. P. 219.

xxv. District head officer, maihalocal government file numbers, 1958, 60/32.

xxvi. Mubi local government official file no. Mub/22/18 (restricted) on the colonial masters, undated.

xxvii. Clark, t., the right honourable gentleman: hudahuda publishing company, zaria, 1991. Pp. $430-540$.

xxviii. John $\mathrm{n}$ paden, ahmadu bello, the sardauna of sokoto, values and leadership in Nigeria: zaria, Nigeria: hudahuda, 1986. P. 65

xxix. Crowder, m., pagans and politicians 1959, the story of Nigeria: London: 1978 Hutchinson. P. 218.

xxx. Dudley, b. F., parties and politics in northern Nigeria, 1968, and politics and crisis in Nigeria, London, Bloomington: Indiana university press. 1978. P. 210

xxxi. Muffett d.j.i let truth be told vol.1 the coup d'état of 1966 (zaria 1966). P.12

xxxii. Gardiner d.e, (1969) 'British Cameroon' the Britain and Germany in Africa: imperial rivalry and colonial ruleyale university press, London, 1969, pp.43-63.

xxxiii. Ibid. P. 219.

xxxiv. Abubakarsaad, (1978) the lamibe of fombina a.b.u press, zaria. P.67

xxxv. Ibid, p.48

xxxvi. Ibid.p,49

xxxvii. Kirk-green a.h.m, (1958) adamawa past and present oxford university press, London's. 132.

xxxviii. Azariuya, victor (1978) aristocrats facing change: the fulbe in guinea, Nigeria and Cameroon. University of Chicago press, chicago.p.95.

xxxix. Meek c k, (1957) land tenure and land administration in Nigeria and the Cameroons, h.m.s.o. London, 1957. P.190.

xl. Abba i a, (1980) sir ahmadu bello the sardauna of sokoto's conversion campaign 1964-1965 in adamawa division and northern sardauna province. Paper presented at a post- graduate seminar, bayero university, kano, Nigeria

xli. Njema, m. Zakari (1969) the rise and fall of fulani rule in adamawa phd. Thesis London, 1969. P. 231

xlii. Abubakar s, the emirate of fombina: the attempt of a politically segmented people to establish and maintain a central form of government. Phd thesis abu zaria. P.127

xliii. Touvan, s. (1920the boundary politics and independent Africa Harvard university press Cambridge Massachusetts, 1920. P.98

xliv. Gardiner d e, (1969) 'the British Cameroons'. In Britain and Germany in Africa: imperial rivalry and colonial rule. (gifford, p. And louis, w.m.r. (eds.) Yale university press, London, 1969.p.197.

xlv. Ibid.

xlvi. Paden j n, (1956) ahmadu bello, the sardauna of sokoto, values and leadership in Nigeria. Richard clay press, bungag. P.212.

xlvii. Abubakar tafawa balewa and shehu umaru (reprinted zaria 1956); London, 1957.p.75.

xlviii. Ahmadu u j. The failure of radical politics in northern Nigeria, (university of Edinburgh msc thesis, unpublished, 1975). P.232

xlix. Amadu k,the Nigerian general elections 1959and 1979 and the aftermath lagos 1983, p.98

l. Crowder m. Pagans and politicians (London 1959) and the story of Nigeria London 1978.p.96.

li. Ibid.p.79

lii. Ahmed a. K, late alhaji the right honourable sir tafawa balewabauchi 1084). P.120.

liii. The general assembly resolution 1608-1350 concerning the future of the trust territory under the united kingdom administration.p.128

liv. Ibid, p,129

lv. General assembly resolution 224 concerning administrative union of the trust territory.p.40

lvi. Ibid, p.56

lvii. Adoh's report on the conduct of the plebiscites for the plebiscites of northern Cameroons in Nigeria, 1959 . P,180

lviii. Ibid, p.184

lix. The trusteeship agreement for the Cameroons under the United Kingdom administration December $13^{\text {th }}, 1946$. P.24

lx. Ibid, p.32

lxi. The administration of the trust territory under mandate and the report of the permanent mandate commission as approved by the general assembly, 1959. P.79

lxii. See also article 10 of the mandate commission report.p.181

lxiii. See also summary record of the general assembly first session, fourth committee part 2 1948, pp. 118-119.

lxiv. Ibid, p.118 
lxv. Ibid, p.119

lxvi. The mandate committee report of 1922.p.123

lxvii. The general assembly of the United Nations resolution 1350 (xiii) (annex v 34) march, $13^{\text {th }} 1959$. The annual report of the trusteeship council 1950.p.86.

lxviii. Levine, t. Victor (1964) the Cameroons, from mandate to independence. University of California press, california.p.99 